\title{
Assessing the Impact of Training on Staff Performance: Evidence from Ghana Health Service in the Kumasi Metropolis
}

\author{
Victoria Timah \\ Faculty of Business Education, College of Technology Education \\ University of Education, Winneba, P. O. Box 1277, Kumasi, Ghana \\ E-mail: timahv37@gmail.com
}

Received: Nov. 8, 2018 Accepted: Dec. 1, 2018 Published: Dec. 22, 2018

doi:10.5296/bmh.v6i2.14093 URL: http://dx.doi.org/10.5296/bmh.v6i2.14093

\begin{abstract}
The quest for quality efficient workforce in the attainment of organizational goals continues to attract attention from organizations in their desire to remain competitive in the business arena. This study sought to assess the impact of training on staff performance at the Ghana Health Service in the Kumasi Metropolis (GHS-K). The research was conducted through questionnaire administration on the impact of staff training and development at GHS-K. The questionnaire was administered to randomly selected health workers at the selected public hospitals and staff of GHS-K. The data collected were analyzed to yield frequencies and percentages of responses. The results showed that In-service training $(85.0 \%)$ as part of on-the-job training types dominate training programmes organized by GHS-Kumasi Metro and that greater number of these programmes are routine $(66.0 \%)$ in nature and as such do not base on training- needs assessment. The study also shows that the organization of training and development programmes at GHS-K has brought some remarkable improvement $(59.0 \%)$ in the performance of employees, and that financial constraints $(64.0 \%)$ and lack of organizational objectives $(54.0 \%)$ pose a challenge to its sustenance. The study concludes that as more training programmes in varying forms are given to employees and right procedures adopted, better performance of job execution will be achieved.
\end{abstract}

Keywords: Training and development, employee performance, training needs assessment, Ghana Health Service 


\section{Introduction}

Human Resources and Organizational Development (HR\&OD) functions are experiencing a lot of criticisms from employees, customers, society and government in their day to day execution of their duties (Daniel, 2001). The Ghana Health Service (GHS) Kumasi metro brought to light problems concerning recruitments, promotions, health and safety issues, motivation, development and many more $(\mathrm{MoH}, 2005)$. The improvement of staff performance has long been associated with an increase in the provision of employee training. The founders of quality practice and 'improved staff performance in manufacturing emphasized the importance of employee development; education and training for the improvement of performance of firms seeking to implement improved staff performance have consistently found it necessary to improve their training efforts (Deming \& Edwards, 1982). Firms pursuing this strategy have found it necessary to invest in human-capital-enhancing activities such as training, in order to enhance performance improvements in productivity and customer satisfaction (Youndit, Snell, Dean \& Lepak, 1996). In recent years, organizations have invested increasing financial and labor- related resources on employee training. The assumption is that training will benefit the organization through improved performance which will result in greater efficiency, greater customer satisfaction and ultimately, increased revenue and profits.

Further, employees are assumed to benefit because their improved performance should lead to career advancement and increased productivity (EDM, 2012). In view of the above, many Organizations are discovering that in order to succeed. There is the need to increase the knowledge base of their employees. A Price water house Coopers survey was cited by Huselid (1995) identifying that 700 out of 1000 fortune companies interviewed, cited lack of trained employees as the number one barrier to growth. Employees require some training in order to manage their work role following the delegation of responsibilities and flexibly respond to changing customer and market requirement. According to Employee Development Manual (2012), training is seen as indispensable in the lives of both Governmental and Non-governmental, Organizations. Organizations in one way or the other need to train its newly recruited and retain existing employees in order to acquaint themselves well with the job. Preparing workers to function effectively in the organization is to boost self-esteem and to ensure their success and development. However, the emphasis now is to make employers and employees more skillful in order to have viable improvement over their competitors at meeting the needs of a very varied range of customers and clients (Brunetto, 2002).

The GHS has committed a lot of financial resources in its training programmes. Each year, the institution allocates about a quarter of its budget to its human resource section to undertake training for the employees to acquire knowledge in management practice. The major objective of this training programmer has been to -equip staff of the service with the knowledge and skills that is required for efficient and effective performance of their duties. Despite all these efforts and the huge sums of money spent on training programmes, public opinion is that the health sector is not performing up to expectation. It is however, worthy to note that, measuring the effects of training on employee performance has been problematic due to the difficulty of isolating the effects of training from other human resource 
management practices and environmental and organizational influences (Adi, 2012). Judging from the above, one is tempted to conclude that in spite of the numerous resources and efforts committed to training by the GHS, the programmes have not been successful in improving performance of the staff and thus the Health sector cannot boast of a high caliber of staff that is knowledgeable, skilled enough to perform their jobs efficiently and effectively without avoidable lapses. This study therefore seeks to assess the impact of training on staff performances in an organization.

\section{Literature Review}

\subsection{Concept of Training}

Training is needed in virtually every business and industry. All types of workplace training require human resources planning since budget and/or company time are involved. Some training is on the job, while other types may involve the company sending employees for outside training paid for by the business. Training sessions and seminars must be factored into a company's time and budget. Training is classically one of the most common human resources issues as it's a necessary component of employee development. HR directors work with the heads of companies to create benefit policies. In human resources, a compensation package refers to salary plus included benefits. Common employee benefits include health insurance, life insurance, a dental plan and employee product discounts. When employees are terminated, benefits are too, so HR must keep records of the exact hiring and termination dates of each employee. Also Training is given on four Basic Grounds:

a) New candidates who join an organization are given training. This training familiarizes them with the organizational mission, vision, rules and regulations and the working conditions.

b) The existing employees are trained to refresh and enhance their knowledge.

c) If any updating and amendments take place in the technology training is given to cope up with those changes. For instance, purchasing anew equipment, changes in technique of production, computer impartment. The employees are trained about use of new equipment and work methods.

d) When promotion and career growth becomes important. Training is given so that employees are prepared to share the responsibilities of the higher level job.

Brunetto (2002) also argued that "Training is linked to employee performance and retention. In addition, employees will not reach their full potential and higher levels of productivity will not be achieved unless employees are adequately trained. A poorly trained work force will eventually lead to poor performance and result in costly mistakes. Overall, training impacts organizational competitiveness, revenue and performance. Unfortunately, when the economy slows or whenJprof1ts decline, many organizations first seek cuts in their training budgets. It is essential for employers to maintain the training necessary to compete. The costs of training can be reduced and controlled through the development of a comprehensive training plan. Additionally, the cost can further be reduced by training employees in-house with the use of 
internal trainers. Also an organization which spends huge sums of money on training does it with the objective of gaining higher returns from the money which it has invested in the training. According to Bateman and Snell (1996) companies such as Motorola, General Motors and International Business Machines (IBM) have invested over billions of dollars in training. The returns on the training enjoyed by these companies far exceed the amount that was invested. In support of this assertion, they emphasized that Motorola has been gaining $\$ 30$ on every $\$ 1$ invested in training. This really shows that companies commit huge sums of money in training with the aim and objective of increasing productivity which will lead to higher returns on the training funds invested. Danso, Adu, Twum-Amposah, and Mprah (2012) further explained that in-service training within Public Service agencies is recognized as a key means through which staff are provided with the necessary knowledge and skills to improve overall institutional performance and achieve the objectives of the organization.

Again, according to Hood (1995), employee training programs or initiatives are an integral part of the HR vision and long-term strategic objectives of an organization. Through timely, controlled and intelligently developed training programs, employees develop requisite capabilities and new skills to perform assigned jobs consistently and successfully. Ultimately, carefully devised and implemented employee training programs should impact organizational competitiveness, long-term performance and overall productivity. Hood (1995) further stated that "Many corporations with well-defined work cultures and best practices believe in fostering employee spirit and motivation. Induction training programs imparting skills-based knowledge and inculcating organizational ethos ease the process of assimilation and prepare employees to tackle their job roles and responsibilities in a focused manner.

Hood (1995) also opines that the dizzying evolution of technologies and IT- based productivity tools calls for periodic employee training and that employees are trained and coached to learn and implement new tools and technologies in the workplace. Attendant industry environment and competitive pressures from companies in the same domain keep an organization on its toes. Skills-based training helps in keeping an organization sharp-edged and competitively attuned to the rigors of doing business. Diversity in the workplace, evolving business models and marketplace positions tend to shape the development and maturity of organizations. Becoming learning organizations is possible through timely, intelligently developed and well-channelized training programs. Hood (1995) also concluded that for organizations to experience long-term productivity gains, sustained performance and overall profitability with well-developed and successfully skills, an implemented employee training programs have to be instituted.

\subsection{Training Methods}

The selection of method for training need to be based on identified training needs, training objectives, an understanding on the part of the trainees, the resources available and an awareness of learning principles. De Cenzo and Robbins (1996) explained that the most popular training and development method used by organizations can be classified as either on-the-job or off-the-job. The writers further acknowledged that there are a variety of training approaches that managers may use. According to Beardwell and Holden (1993), many 
organizations often use inappropriate methods which can be both costly and time wasting and this will bring little improvement in the performance of the employees. Cascio (1986) commenting on the selection of training methods for training employees, an organization should choose a training method that:

- Motivates the trainee to improve his or her performance,

- Clearly illustrates the desired skills,

- Provides for active participation by the trainee,

- Provides an opportunity for practice,

- Provides timely feedback on the trainee's performance.

\subsection{On-the-Job Training}

Considering some of the forms that on-the-job training can take, De Cenzo and Robbins (1996), and Eraut, iklderton, Cole and Senker (1998) are of the view that the most popular ones are apprenticeship training and job instruction training (JIT). To them, job "instructional training was developed during the World War II by the War Manpower Commission to prepare supervisors to train employees. They are of the view that JIT consists of four main stages which the trainer needs to follow. The stages according to them are to prepare the trainees, present the trainee, try out the trainee and follow up. The purpose of the initial stage according to the De Cenzo and Robbins (1996) is to motivate the trainees. It requires the trainer to analyze the job in question into its major components, to prepare an instruction plan that proceeds from simple to more advanced material in a logical fashion. It is also at this stage that the trainer needs to put the trainee at ease by building his confidence. The purpose of second stage is based on the findings of Eraut, Alderton, Cole and Senker (1998), and De Cenzo and Robbins (1996) which is to promote understanding on the part of the trainee. To do this, it is necessary for the trainer to show, tell and demonstrate what the trainee is supposed to do at the work place. This helps to measure in advance the capability of the trainee.

The purpose of the third stage is to foster active participation by the trainee. The trainer should let the trainee try out the job in order to demonstrate his understanding. Errors need to be corrected at this stage. The trainer at this stage will have to review and retrain the trainees until he is satisfied with the level of performance. By this the trainer is sure of the conformity of work performance by the trainee and that there is hope that the output will be standardized. The purpose of the final stage is to apply what was learned by letting the trainees perform the work on their own. It is also necessary to check the trainees frequently at first, encouraging questions and telling them where they should go for help in case they are in difficulty. According to the writers, by going through the above stages to embark on job instruction training (JIT), studies have indicated that employees' accidents have been minimized. 


\subsection{Off- the- Job Training}

According to De Cenzo and Robbins (1996), Off-the-job training gets employees away from their work environment to a place where their frustrations and bustle of work are eliminated and that the relaxed environment can help employees to absorb more information as they feel less under pressure to perform. The idea of getting employees to undergo training outside the job environment can be in various forms, among these are: lectures, audio-visual methods, role playing, programmed instruction and vestibule training etc. They further assert that off-the-job training can be a training method employed by organizations to serve as a source to 'supply the latest information, current trends, skills and techniques. Example of this development could be current employment legislation or other company law and regulations, current computer software or computerized technologies or improved/innovative administrative procedures. These new skills can be brought back and utilized within the company. In their contributions on the subject of off-the-job training method in employee training and development, Billett (2001); Dymock and Gerber (2002), and Winch and Ingram (2002) opine that Off-the-job training where learning assignments are related to problem-solving and task- centred activities linked to the strategic business intent of the organization could bring experts in their fields on board and enables them to cover various course modules, and in consequence make training for staff members be taught to a reasonable standard. He also explains that as the training courses are held externally, organizations would not have to border on added costs incurred as a result of extra equipment or additional space. The idea of sending an employee on a course has the advantage of helping the employee feel more valued as they would feel as if they are receiving quality training and as many courses or seminars are organized this way, employees from other companies might attend thereby allowing them to network and perhaps drum-up business.

However, according to Dymock and Gerber (2002), adopting Off-the-job training method alone is not good enough as this has the tendency to increase the overall cost of training, making the training quite expensive in the sense that many courses may require an overnight stay at a hotel if the course is outside the area or the course itself may prove to be expensive due to the level of expertise or equipment needed to deliver the course. Another area the adoption of off-the-job training method could be a problem is the fact that there might not the opportunity to know the abilities both as a trainer and their subject knowledge of the people delivering the external training courses, giving no guarantee that sufficient skills of knowledge will be transferred-to the trainees.

\subsection{Training, Performance and Organizational Profitability}

The quality of employees and their development through training are major factors in determining long-term profitability and optimum performance of organizations. To hire and keep quality employees, it is good policy to invest in the development of employees' skills, knowledge, abilities and capabilities so that individual and organizational productivity can increase. Training should be ongoing for existing and new employees to help them adjust rapidly to changing job requirements. Organizations that are committed to quality, invest in the training and development of its employees (Evans \& Lindsay, 1999).In a study in America 
on the impact of human capital investments such as employer-provided training and development, Black and Lynch (1996) citied by Batt (2002), indicated that employerprovided training and development raises subjective productivity and performance measure by almost 16\%. And this confirms Brunetto (2002), Bateman and Snell (1996), quoted earlier that returns from training always exceeds what was invested in the training.

\section{Method}

\subsection{Setting of the Study}

This study adopts discipline research design through the use of questionnaire in order to collect relevant data from respondents (Nachmias \& Nachmias, 1996) at Ghana Health Services professionals in the Kumasi Metropolis. The Ghana Health Service provides Clinical and Public Health Services through hospitals and clinics and static and outreach stations (Public and Private). It has its headquarters in Accra and directorates in all the regional capitals in the country. The Kumasi Metro directorate is endowed with many Hospitals, Clinics, Maternity Homes and Outreach Stations and therefore accessibility to services in terms of distance is good. There are 15 Private Laboratories in addition to the Laboratories in the various hospitals.

The Kumasi Metropolitan health service is organized around many hospitals, Clinics and maternity homes. There are 6 public hospitals including KATH, 6 public health centres, 3 mission hospitals, 3 quasi government hospitals and more than 200 hospitals and maternity homes. Services offered include Clinical care, prevention of diseases and health promotion activities. The health service also has about 672 pharmacy and 510 chemical shops in the metropolis providing adequate health care to the citizenry $(\mathrm{MoH}, 2005)$.

Table 1 shows the distribution of Health Facilities, Private Laboratory service and outreach stations in Kumasi.

Table 1. Health Institution per Sub-Metro Health Areas

\begin{tabular}{llllllllll}
\hline SM & GH & QGHC & MHC & PH & PC & MH & HC & PL & OS \\
\hline Asokwa & 1 & 1 & 1 & 14 & 22 & 18 & 3 & 1 & 47 \\
Bantama & 1 & 0 & 1 & 15 & 16 & 12 & 0 & 7 & 36 \\
Manhyia North & 1 & 0 & 1 & 5 & 10 & 16 & 13 & 2 & 41 \\
Manhyia South & 1 & 0 & 0 & 7 & 8 & 6 & 4 & 2 & 25 \\
Subin & 2 & 3 & 0 & 3 & 11 & 3 & 0 & 3 & 20 \\
Total & 6 & 4 & 3 & 44 & 67 & 55 & 20 & 15 & 169 \\
\hline
\end{tabular}

*SM=Sub- metro; $G H=$ Government hospital; $Q G H C=$ Quasi government hospital and clinic; $M H C=$ Missi0n hospital and clinic; $P H=$ Private hospital; $P C=$ Private clinics; MH=Maternity home; HC= Homeopathic clinic; PL: Private laboratories, and OS =outreach stations.

Sources: Ghana Health Service, Kumasi Metro’s Annual Report. 


\subsection{Research Design}

This study adopts the descriptive research design. This is to enable the researcher to collect relevant data from the participants which will help give answers to the research questions posed as a guide to the study on the impact of training on staff performance at Ghana Health Service, Kumasi-Metro. Furthermore, descriptive survey had found to be one of the most widely used methods in the collection of data to facilitate answering the study's research questions. Its ability to provide both qualitative and quantitative description of trends, attitudes, or opinions of the population was also seen as remarkable (Nachmias \& Nachmias, 1996).

\subsection{Population and Sample Size Selection}

The target population for the study comprised employees and management staff at the health directorate and selected hospitals in the various sub-metros of Kumasi. The health directors, doctors, nurses, administrative assistants and other supportive staff in the hospitals thus constitute the population of the study. The study therefore focused on the management, senior members, senior and junior staffs of the selected station-the headquarters. These categories of workers were known from initial visits to the institute which presented very good account of different types of workforce. Thus the sampling unit for the study comprised the individual persons working at the various hospitals.

The sample size for the study was chosen based on the assertion in Nachmias and Nachmias (1996), that if the population are few hundreds, a $30 \%$ or more sample size will do; if several hundreds, a $20 \%$ sample size will do, if a few thousands, a $10 \%$ sample will do; and if several thousands, $5 \%$ or less sample size will do. The total population for the 5 worker categories for the study was 333. The sample size of 100 respondents was selected from 333 workers to specifically provide information that would be relevant to the study. Out of the total respondents of 100, 7 workers representing $30 \%$ were selected from a total of 23 doctors, 48 workers representing 30\% from 160 nurses, 16 workers constituting 30\% were selected from a total of 53 administrators with 12 workers selected from 40 pharmacists while 17 workers representing $30 \%$ were also selected from a total 57 workers in the paramedics staff category (Table 2). The selection of the workers according to their total number in the various hospitals and health directorate office was deemed appropriate due to the researcher's intention of having a fair representation of the various worker categories. Table 2 gives the selection of sample size used for the study.

Table 2. Sample size of selected workers

\begin{tabular}{llll}
\hline House Type & Population & Percentage (\%) & Sample Size \\
\hline Doctors & 23 & 30 & $30 / 100 * 23=7$ \\
Nurses & 160 & 30 & $30 / 100 * 160=48$ \\
Administration & 53 & 53 & $30 / 100 * 53=16$ \\
Pharmacists & 40 & 30 & $30 / 100 * 40=12$ \\
Paramedics & 57 & 57 & $30 / 100 * 57=17$ \\
Total & 333 & 30 & 100 \\
\hline
\end{tabular}


The researcher employed the use of systematic sampling technique for the selection of the cases for the study. Systematic sampling technique was used to select the workers from the various worker categories because of its simplicity. This method involves identifying, listing and numbering all the workers in the study area. Where $\mathrm{S}$ represents the total number of workers in each category and $\mathrm{R}$ the required number of workers to be selected, a skip interval $\mathrm{I}=\mathrm{S} / \mathrm{R}$ was calculated. This was calculated to be 3 for all worker categories in the institute. The first worker was selected by adding the skip interval 3 to a randomly picked number between 1 and the interval. Subsequent workers were selected by adding the interval to the last serial number (Afolabi, et al., 2010).

\subsection{Data Collection Technique}

The data collection technique was through structured questionnaire administration. Questionnaire as data collection instrument was deemed appropriate in gathering essential data necessary to assess to the impact of training on staff performance in the GHS, Kumasi metropolis. This was due to its advantage in covering greater number of respondents and quicker way of gathering data. The questionnaire was ministered to the various respondents sampled for the study. These include the Director and all staff of the GHS Kumasi Metro as well as the health workers in the selected hospitals within the Kumasi metropolis.

The questionnaire was divided into six sections: respondents' personal information, training needs of staff, impact of training on staff performance at the GHS-Kumasi metro, the implication of lack of training on staff performance at the GHS, challenges faced by GHS management in offering training and recommendations for the provision of effective and efficient training for the staff of GHS-Kumasi metro. The questionnaire was made up of thirty-three (33) items structured in the same way to ensure that all respondents answer the same questions. It involved both open and close ended questions.

Again secondary sources of data in decentralization of health care delivery both published and unpublished as well as the internet were also used to supplement the field information. The questionnaire was administered and collected by the researcher. A total of 100 questionnaires were administered to the employees comprising doctors, nurses, pharmacists, administrators and paramedics in the various hospitals and the metro health directorate office personally by the researcher and an assistant for completion. The questionnaire was accompanied by a statement of the objective of the study to facilitate the answering of the items.

In all, three steps were followed in the administration of the questionnaire to encourage a good response. The first step was an advanced-notice and contact appropriate authorities in the hospitals. This was meant to seek assistance from the authorities in reaching out to the selected respondents and also to familiarize with the respondents as way of encouraging their participation. The second step was on the distribution of the actual questionnaire with an accompanying personalized, signed cover letter. This was expected to last for two weeks, one week after the advance- notice letter as recommended in (Nachmias \& Nachmias, 1996). All the respondents were able to read and understand the questionnaire items and therefore completed the questionnaire independently. The final step was the collection of the 
administered questionnaires, personally by the researcher and the attendants. The completed questionnaires were collected from the respondents and screened for the detection of any errors; and finally numbered accordingly by the researcher for analysis and discussion.

\subsection{Validity and Reliability of Instrument}

To ascertain the reliability and validity of the variables and whether they were well understood by respondents, the questionnaire was pre-tested by the researcher. This afforded the researcher the opportunity to find out the flow and logical sequence of questions as well as the average amount of time needed to administer a questionnaire. Indeed, this technique helped to determine the average number of questionnaires to be allocated to respondents during the main fieldwork. The pre- testing was undertaken at the Kase government hospital in Kase. The sample was drawn from the registry of the hospital. A total of 10 respondents were given questionnaires to complete. This was carried out by the researcher herself. The overall Cronbach's alpha (1) for the factors items was 0.64 . The purpose of this was to test the research instrument, and to make any necessary amendments. It was revealed at the pre-testing stage that a questionnaire was estimated to take about ten minutes on the average to complete. The length of questionnaire was adequate. Thus, the results of the initial piloting helped in restructuring the questionnaire and making the necessary corrections where needed.

\section{Results and Discussion}

\subsection{Demographic Statistics}

Table 3 gives the frequency distribution and percentage of the respondents in the various demographic variables considered. With regards to gender of the respondents, Table 3 shows that majority of the respondents selected for the study were in the female category as this recorded 60 per cent of the selected sample size compared to 40 per cent recorded by the male gender group. This development could be attributed to the dominance of females in the staff distribution of the GHS as most of the staff employed are in the nursing category $(\mathrm{MoH}$, 2005). The implication of this is that any training programme organized should give reverence to gender influence.

Touching on the age range of respondents, the modal age range for the overall sample was 20 -39 with 60 per cent of respondents falling in this range. About two-fifth of the respondents, ( 40.0 per cent) were above the age of 40 years which indicated a higher level of workplace experience (Table 3). None of the respondents were below the age of 20 years. The majority of the respondents falling within youthful age bracket could be traced to the demand of the job in the health sector as most jobs require higher energy performance to meet the growing needs of patients who besiege the public for medical attention. Any worker employed in these hospitals is expected to cope with pressure exerted by the public as spelt out in the Ghana Health Service policy guidelines $(\mathrm{MoH}, 2005)$. This development indicates that the organization of any training programme meant to improve staff performance should focus on the learning needs of the youth, as the core of the staff fall within this age bracket. By doing this, the objectives of conducting staff training in GHS-K would be realized, reducing the daily pressures confronted by health workers. Winch and Ingram (2002) opined that an 
important consideration of any training regime is the cost incurred and the need to recoup the cost when employees contribute effectively to the organization. The implication of this is that any investment made in the training of staff will be beneficial to the organization.

The implication of this is that any investment made in the training of staff will be a beneficial to the organization.

In terms of academic qualification, Table 3 shows that most (47.0 percent) of the respondents had degree as their qualification followed by diploma qualification (41.0 per cent) while Higher National Diploma (HND) and Secondary recorded the lowest percentage as these recorded 6 per cent respectively. The indication of this is that health care delivery requires highly specialized skills and qualification so as to meet the aspirations of patients and the general public and also cope with the changing trend in health care delivery. Employing high qualified personnel in the dispensation of health care delivery could also be attributed to the importance attached to health care delivery by the GHS. The implication of this is that any training programme organized for health workers should be more relevant to the needs of most qualified personnel. The profession of respondents in healthcare delivery affects the training dynamics of health workers in the quest to improve their performance in the GHS. According to Table 3 Nursing profession dominates the staff distribution in the GHS-K as this recorded the highest in terms percentage ( 48.0 per cent) followed by other paramedical personnel notably ward assistants, laboratory technicians and medical assistants which recorded 27 per cent while doctors were the least in terms of provision in the hospitals. This could be attributed to the major roles performed by the personnel and their availability and as such most jobs in the hospital are performed by the nurses $(\mathrm{MoH}, 2005)$. This implies that the issue of general nursing should be given the prominence in the selection of training programmes for staff in the GHS as their influence in staff distribution continues to increase.

The years of service in the organizations became a factor in answering the questions. Table 3 shows that a little below four-fifth $(79.0$ per cent) of the respondents had been in the health sector for more than six years while about one-fifth ( 21.0 per cent) had worked for about five years or below. The indication of this is that answers provided by respondents on the impact of training on their performance could much rely on because of their long working experience. This development is very crucial" to the success of the organization as experience of personnel in any organization sometimes impact positively in the overall performance of the organization as observed by Susan (2012). 


\section{Macrothink \\ Business and Management Horizons \\ ISSN 2326-0297 \\ 2018, Vol. 6, No. 2}

Table 3. Demographic characteristics of respondents

\begin{tabular}{|c|c|c|}
\hline Demography & Frequency & Percentage (\%) \\
\hline \multicolumn{3}{|l|}{ Gender } \\
\hline Male & 40 & 40.0 \\
\hline Female & 60 & 60.0 \\
\hline \multicolumn{3}{|l|}{ Age range (years) } \\
\hline$<20$ & 0 & 0.0 \\
\hline $20-29$ & 30 & 30.0 \\
\hline $30-39$ & 30 & 30.0 \\
\hline $40-49$ & 20 & 20.0 \\
\hline 50 and above & 20 & 20.0 \\
\hline \multicolumn{3}{|l|}{ Qualification } \\
\hline Secondary & 6 & 6.0 \\
\hline Diploma & 41 & 41.0 \\
\hline Higher National & 6 & 6.0 \\
\hline \multicolumn{3}{|l|}{ Diploma } \\
\hline Degree & 47 & 47.0 \\
\hline \multicolumn{3}{|l|}{ Profession } \\
\hline Doctor & 7 & 7.0 \\
\hline Nurse & 48 & 48.0 \\
\hline Administrative & 16 & 16.0 \\
\hline \multicolumn{3}{|l|}{ Assistant } \\
\hline Others & 29 & 29.0 \\
\hline \multicolumn{3}{|l|}{ Years in service } \\
\hline $1-5 y r s$ & 21 & 21.0 \\
\hline $6-10 \mathrm{yrs}$ & 46 & 46.0 \\
\hline $11-15 y r s$ & 8 & 8.0 \\
\hline $16-20 y r s$ & 3 & 3.0 \\
\hline $21 \mathrm{yrs}$ and above & 22 & 22.0 \\
\hline
\end{tabular}

Source: Researcher's field data.

\subsection{On the Job Training Programmes}

Table 4 reports of the percentage responses of respondents in the GHS-K in the kind of training provided by management on the improvement of staff performance in the organization as in service. From Table 4, in-service training appears to be the most dominant training programme organized by management in quest to improve staff performance in the GHS-K as it recorded 87.0 per cent of a total of 100 respondents. This is followed by 'Workshop' which recorded 69.0 percent of the total number of respondents while Case conference form of training appeared to be the least training programme embarked upon by the management of the GHS-K as it recorded percentage score of 14.0 out of a population of 100 respondents. 
This development could be attributed to the knowledge base of management on the current trends in employee training which places much emphasis on in-service training as a results of its ability to provide employees with the necessary knowledge and skills essential in the improvement of the overall institutional performance and attain the objectives of the organization. The implication of this is that trainee programmes given to respondents will be tailored to their needs based on the current trends in employee training as asserted by Danso et al. (2012) that type of trainee programme organized to employees come in various forms depending on the main objectives of the training and that theses trainings facilitate employees learning thereby modifying their behaviour in contributing to the organizations goals and objectives.

Table 4. On the-job Training Programmes Organised for Respondents by GHS-K

\begin{tabular}{cccc}
\hline Training type & $\mathrm{N}$ & Frequency & Percentages (\%) \\
\hline In-service training & 100 & 85 & 87.0 \\
Orientation & 100 & 57 & 57.0 \\
Workshop & 100 & 69 & 69.0 \\
Seminar & 100 & 46 & 46.0 \\
Case conference & 100 & 14 & 14.0 \\
\hline
\end{tabular}

Source: Researcher's field data.

\subsection{Importance of Training Needs in Employee Training}

Table 5 reports of the frequency and percentage distribution of respondents' level of agreement on the essence of training needs assessment training programmes in staff training and development. From Table 5, statements 'Every organization must have a list of training needs for staff, training needs differ from organization to organization', 'The permission of training on needed skills are very essential to employee performance' recorded percentage responses of $90.0 \% ; 100.0 \% ; 83.0 \%$ and $97.0 \%$ in that order. This means that respondents strongly agree to the idea of organizations having training needs list for its staff in any training programme and the idea of training needs being different from organization to organization. Additionally, respondents appear to agree in the strongest terms that tailoring training programmes on employees' needed skills is very essential to their performance in the organization.

It could be also seen from Table 5 that statements 'Organizations that do not pay attention to training needs always record low performance face by staff; and Identification of training needs is based on observation or priorities of the organization" also recorded percentage responses of $73.0 \%$ and $63.0 \%$ respectively. The indication of this is that respondents appear to be in the strongest agreement or agreement that any organization that do not pay attention to training needs stand to record low performance from its employees and that the needs of employees can best be identified on the observations or priorities of the organization. 
The development of these responses on the levels of agreement of respondents on the training needs assessment as an essential ingredient to the success of any training programme could be attributed to the awareness of respondents on the importance of identifying their needed skills as a basis for the organization of any training programme in their establishments. This outcome appears to confirm to an assertion by Brunetto (2002) that the preparation of any training policy in an organization should put in place mechanisms to involve employees as major stakeholders and beneficiaries because of the understanding in their own personal needs. The implication of this is that organisers of any training programme in the GHS-K should devise strategies to bring on board the inputs of employees because of their understanding on needed skills crucial to the execution of their job performances.

Table 5. Descriptive Statistics on the Importance of Training Needs in Employee Training

\begin{tabular}{lll}
\hline Statement & $\begin{array}{l}\text { Strongly Agree or } \\
\text { Agree \% (N) }\end{array}$ & $\begin{array}{l}\text { Strongly Disagree or } \\
\text { Disagree \% (N) }\end{array}$ \\
\hline $\begin{array}{l}\text { Every organization must have training list } \\
\text { Training needs differ from organization to organization }\end{array}$ & $\begin{array}{l}90.0(90) \\
100.0(100)\end{array}$ & $\begin{array}{l}10.0(10) \\
0.0(0) \\
17.0(17)\end{array}$ \\
$\begin{array}{l}\text { Training based on needed skills is very essential to } \\
\text { employee performance }\end{array}$ & $83.0(83)$ & $3.0(3)$ \\
$\begin{array}{l}\text { Organization's refusal to pay attention to training needs } \\
\text { result to staffs' low performance }\end{array}$ & $97.0(97)$ & $27.0(27)$ \\
$\begin{array}{l}\text { Identification of training needs is based on observation or } \\
\text { priorities of the organization }\end{array}$ & $73.0(73)$ & $37.0(37)$ \\
Training needs are self-motivated & $63.0(63)$ & \\
\hline
\end{tabular}

Source: Researcher's field data.

\subsection{Impact of Training on Performance}

On the issue of the impact of training programmes on the performance of the organization itself, Table 6 reveals that almost all the respondents (97.0\%) agree or even stronger that human resource development is important in all sections of the economy since it affects the progress of the whole society. The indication of this is that employee training appears to directly enhance the performance of organizations as employees stand the chance of being exposed to the knowledge of general skills in the organization. According to Table 6 organizations stand to benefit from higher performance from their employees as these statements recorded percentage agreement responses of $86.0 \%$ and $90.0 \%$ respectively. These results seem to confirm Brunetto (2002) opinion that training improves morale of employees, give them a sense of job security and job satisfaction and that as the more satisfied employees are the greater to their resolve to contribute to the organizations success.

They also affirmed that training enhances job supervision as attitudes of employees are oriented to get the job well done with little supervision. To the employer, they assert that training allows them to locate a wider range of people with the kind of outlook that matches 
the company's mission statement and that it offers employers an improved retention rate. The implication of this to managers of organizations such as GHS-K who are committed to the provision of quality healthcare to the Ghanaian public especially the division of human resource management and development should commit more resources to the training of their employees as this seeks to go a long way to get better employees and also improve the performance of their organizations which in a long run help to raise their corporate image as leaders in health care provision.

Table 6. Descriptive Statistics on the Impact of Training on Organization's Performance

\begin{tabular}{lll}
\hline Statement & $\begin{array}{l}\text { Strongly Agree or } \\
\text { Agree \% (N) }\end{array}$ & $\begin{array}{l}\text { Strongly Disagree or } \\
\text { Disagree \% (N) }\end{array}$ \\
\hline $\begin{array}{l}\text { Human resource development is important because it affects } \\
\text { the progress of the whole society }\end{array}$ & $97.0(97)$ & $3.0(3)$ \\
$\begin{array}{l}\text { Employee training directly enhance organizations } \\
\text { performance } \\
\begin{array}{l}\text { Organization which offers high level of training for staff is } \\
\text { likely to perform well }\end{array}\end{array}$ & $86.0(90)$ & $14.0(14)$ \\
\hline
\end{tabular}

Source: Researcher's field data.

\section{Concluding Remarks}

This study sought to assess the impact of training on staff performance at the Ghana Health Service in the Kumasi Metropolis (GHS-K). It could be observed that GHS, Kumasi Metro do sometimes organise training programmes for their employees. These training programmes mostly concentrate on In-service training and workshops to address some immediate health challenges or orientate their minds towards new developments in the health sector as evidenced by the findings of the study that greater percentage of training programmes are either In-service training or Workshops. Other forms of training such as Case Conference and On-the-Job training are not given much attention by the health directorate, making the training programmes inadequate and one sided and thereby incapable of achieving all the objectives of employee training programmes in the GHS, Kumasi Metro. Additionally, these staff training programmes at the GHS, Kumasi Metro are mostly done on routine basis with very few being organized as results of the outcome of training needs assessment. Since most training programmes at the GHS, Kumasi Metro, are not organized based on training needs assessment, the right calibre of people qualified for training programmes are most at times denied the opportunity of being enrolled which in consequence, make them unable to improve upon their performance in the execution of their expected roles, thereby defeating the rational of embarking on employee training programmes at the GHS, Kumasi Metropolis. Finally, it can be concluded that staff training programmes organized by management of GHS-Kumasi metro directorate have impacted positively on the performance employees in health care delivery. These have given them the impetus to confidently apply knowledge and 
skills acquired at training to their job performance, a development which the employees less dependent superiors for a given work done.

Based on the findings of this study, the researcher proffers the following recommendations to help improve the training programmes to achieve their desired goals. First, the Ghana Health Service (GHS), Kumasi metro directorate should revise and expand their training programmes to reflect modern organizational training programmes taking into consideration the benefits other forms of training such as Case Conference. Secondly, training programmes organized at GHS-Kumasi metro directorate should be well structured and developed along employee needs assessment so as to make it more responsive to the needs of the employees and capture the right caliber of employees-well qualified for training. This, when done, will go a long way to affect positively the performance of the staff, thereby promoting organizational success. Additionally, there is evidence that training programmes when organized for staff development and increased work performance has the tendency to inject deficiency in work delivery, therefore, outfit in charge of staff training and development at GHS-K metro should increase the frequency of such programmes for their staff so as to maximise their fullest potential. Finally, the human resource training and development sections in the GHS-Kumasi metro should embark on innovative strategies to secure additional funding to finance their training budget which has the tendency to increase staff performance and efficiency. People positioned in such areas should be charged with the responsibility of developing the training sector spelling out in detail their financing strategies so as to reduce the pressure on the central government financing scheme.

The researcher cannot conclude without highlighting other areas of further research such as the impact of external training on staff performance, evaluation of staff appraisals, and the effects of retirement/ resignation of experienced staff on job performance.

\section{References}

Adi, N. A. (2012). Driving performance and retention to employee engagement: A case study in University of Brawijaya. Journal of Basic and Applied Scientific Research, 2(1), 338-350.

Afolabi, O. A., Awosola, R. K. A., \& Omole, S.O. (2010). Influence of emotional intelligence and gender. Current Research Journal of Social Sciences, 2(3), 147-154.

Bateman, T. S., \& Snell, S. A. (1996). Management: Building Competitive Advantage (3rd ed.). Chicago: Irwin.

Batt, R. (2002). Managing customer services: Human resource practices, quit rates, and sales growth. Academy of management Journal, 45(3), 587-597.

Beardwell, N., \& H-olden, B. (1993). Managing for success (2nd ed.). London: Prentice Hall Publishers.

Billett, S. (2001). Learning through work: workplace affordances and individual engagement. Journal of Workplace Learning, 209-214. https://doi.org/10.1108/EUM0000000005548 


\section{Macrothink}

Business and Management Horizons

ISSN 2326-0297

2018, Vol. 6, No. 2

Black, S. E., \& Lynch, L. M. (1996). Human-Capital Investment and Productivity. The American Economic Review, 86(2), 88-98.

Brunetto, Y. (2002). The impact of growing managerialism amongst professionals in Australia: a comparative study of university academics and hospital nurses. Research \& Practice in Human Resource Management, 10(1), 1-25.

Cascio, W. F. (1989). Managing human resources (p. 251). New York, NY: McGraw-Hill.

Daniel, R. (2001). Human resources services, oasis outsourcing. London: York Publishers.

Danso, H., Adu, M. K., Twum-Ampomah, M. K., \& Mprah, R. K. (2012). Evaluation of in-service training for senior staff of a public university in Ghana. Evaluation, 3(7).

DeCenzo, D. A., \& Robbins, B. (1996). Human Resources Management (5th ed.). John Walley \& Sons.

Deming, W. E., \& Edwards, D. W. (1982). Quality, productivity, and competitive position (Vol. 183). Cambridge, MA: Massachusetts Institute of Technology. Center for advanced engineering study.

Dymock, D., \& Gerber, R. (2002). Unintegrated training? Exploring links between off- and on-the-job learning. Education and Training, 44(1), 23-30. https://doi.org/10.1108/00400910210416219

Employee Development Manual (EDM). (2012). Employee training and development.

Eraut, M., Alderton, J., Cole, G., \& Senker, P. (1998). Development of Knowledge and Skills in Employment (Brighton, University of Sussex, Institute of Education, Research Report No. $5)$.

Evans, J. R., \& Lindsay, W. M. (1999). The management and control of quality (4th ed.). Ohio: South-Westem College Publishing.

Hood, C. (1995). Emerging issues in public administration. Public administration, 73(1), 165-183. https://doi.org/10.1111/j.1467-9299.1995.tb00822.x

Huselid, M. A. (1995). The impact of human resource management practices on turnover, productivity, and corporate financial Performance. Academy of Management Journal, 38, 635-672.

Ministry of Health (MoH). (2005). Health delivery in Ghana. Accra: MoH Press.

Nachmias, C. F., \& Nachmias, D. (1996). Research Methods in the Social Sciences (5th ed.). London: Arnold.

Schonberger, R. J. (1994). Human resource management: Lessons from a decade of total management and reengineering. California Management Review, summer, 103-123. https://doi.org/10.2307/41165769

Susan, R. (2012). Importance of human resource management. Journal of Human Resource 
professional, 87(6), 188-201.

Winch, A., \& Ingram, H. (2002). Re-defining the focus of workplace learning. International Journal of Contemporary Hospitality Management, 14(7), 361-367. https://doi.org/10.1108/09596110210440666

Youndt, M. A., Snell, S. A., Dean Jr, J. W., \& Lepak, D. P. (1996). Human resource management, manufacturing strategy, and firm performance. Academy of management Journal, 39(4), 836-866.

\section{Copyrights}

Copyright for this article is retained by the author(s), with first publication rights granted to the journal.

This is an open-access article distributed under the terms and conditions of the Creative Commons Attribution license (http://creativecommons.org/licenses/by/4.0/). 